\title{
ARTIFICIAL, CHEAP, FAKE: FREE ASSOCIATIONS AS A RESEARCH METHOD FOR OUTDOOR BILLBOARD ADVERTISING AND VISUAL POLLUTION
}

\author{
MAREK URBAN, ${ }^{1}$ DANY JOSUÉ VIGIL AVILÉS, ${ }^{2}$ MILOŠ BOJOVIĆ ${ }^{2}$ \\ and KAMILA URBAN ${ }^{3,4}$
}

\begin{abstract}
The free association method is often employed in marketing research to investigate perceptions of a particular product or brand in different socio-cultural groups of customers. In our research, international and domestic students produced free associations in response to photographs of outdoor billboards from two different locations in one city (city centre and outskirts). The results indicate that free associations can depict qualitative aspects of outdoor billboards like poor quality (relating to the categories of amateurish and fake), problematic content (relating to female stereotypes, gender stereotypes and cultural differences), and that they have the potential to capture the general atmosphere of the neighbourhood (categories of decay, depression, danger and past).
\end{abstract}

Keywords: outdoor advertising; billboards; visual pollution; marketing research; free associations

\section{Introduction}

Visibility, media effectiveness, local presence and potential tangible response are four key reasons why advertisers use outdoor billboards (Taylor, Franke, \& Bang, 2006). Visibility refers to the ability of being easily seen and making a strong impression 24 hours per day. Media effectiveness reflects the extensive reach of billboards within a small designated area at a relatively low cost per thousand exposures. Local presence is connected to the belief that billboards enable brand recognition among customers in geographical proximity to the business location. The last of these, tangible response, refers to the expectation that customer traffic and sales will increase. To achieve these, billboards-defined as "large format advertising displays intended for viewing from extended distances, generally more than 50 feet" (OAAA, 2019) — are often located in high-traffic areas, where they can be repeatedly seen and seamlessly accessed by the general public.

As a recent meta-analysis of public polls in the United States suggests, US consumers view billboards positively, and the large majority of people do not support billboard bans (Franke \& Taylor, 2017). The growing number of billboards is, however, becoming a reason for concern. They are considered to be an aesthetically displeasing structural disruption of

DE GRUYTER 
the urban environment and are often insensitive to the local culture and traditions (Nowghabi \& Talebzadeh, 2019). For these reasons, the term 'visual pollution' is employed in the research (Baker, 2007; Chmielewski, Lee, Tompalski, Chmielewski, \& Wężyk, 2016) and its individual and social consequences are discussed (Portella, 2014).

Correa and Mejía (2015) argue in their research that the physiological impact of high levels of visual pollution in Ecuador's main city, Quito, is increasing stress levels, eyestrain and headaches. Similarly, Nowghabi and Talebzadeh (2019) argue that visual pollution in the second largest city in Iran, Mashhad, causes mental confusion and reduces intellectual concentration, and that its effects and consequences are accumulating over time.

More importantly, the negative effect of exposure to billboards displaying foreign cultural traits (such as the objectification of sexuality; Lloren, 2017) and age-inappropriate products (such as tobacco in the vicinity of schools; Vardavas, Connolly, \& Kafatos, 2009) is emphasized. Pacoma (2017, p. 1), in his content analysis of billboards in the Philippines, articulates the conflicting idea of a "nation rich in morals, values and principles but [supporting] high profanity or obscenity through sexualized male bodies as seen in billboards of fashion brands and gratification of visual desire among its spectators". As a result of their in-depth interviews, Hartono, Davies and Macrae (2017, p. 179) state that:

\footnotetext{
Muslim mothers in Indonesia find many roadside billboards confronting, especially those advertising harmful products such as cigarettes or using sexualised images of women. This unease is exacerbated by the fact that during daily commutes neither they nor their children can avoid seeing these billboards. However, while billboards pose a challenge to Islamic sensibilities, some Muslim mothers use these billboards as sites to educate their children about piety, modesty and tolerance.
}

This re-framing of the original meaning by Indonesian women can be understood as a unique coping strategy requiring a great deal of wilful effort. Stocchetti $(2014 ; 2017)$ explains that the meaning of images is always the result of negotiation between the images and social actors who are willing to participate in the communicative process. However, social actors are forced to participate in communication with outdoor advertising because they cannot choose not to look. The public is therefore obliged to engage with meanings that may contradict its cultural norms or traditions. This raises the question, "How can we access the meaning the public infer from communication with billboards?". To answer this question, we suggest in the next section that free associations provide a suitable method.

\section{Free associations}

The use of free associations was originally adopted for psychotherapeutic purposes by Sigmund Freud who wished to explore the unconscious contents of his psychoanalytic patients. Patients were free to, and encouraged to, produce associations (on target terms relevant to the therapeutic session, like 'mother' or 'sex') that infused the conscious meaning of their words with hidden feelings, memories, affections, sensations and sense of self. This technique is based on unconscious thinking and is more suitable for working with traumatic topics than in-depth interviews are, because it does not directly activate psychological defence mechanisms (Bollas, 2008; Kris, 2018). 
Nowadays, free associations are frequently used in social psychology, because as the research suggests, a number of the first associations are shared by a sociocultural group. The more associations participants are asked to write down, the more personal the content becomes (Dany, Urdapilleta, \& Lo Monaco, 2014; Plichtová, 2002; Rosen \& Russell, 1957; Rozin, Kuzer, \& Cohen, 2002). Time or space restrictions are therefore employed in social psychology. For example, participants have to write down their associations within one minute (Rozin et al., 2002), or only the first one or three associations are analysed in the research (Halamová, Baránková, Strnádelová, \& Koróniová, 2018).

In qualitative research, a whole variety of target concepts are examined to find which words and word categories are associated with them (Nelson, McEvoy, \& Dennis, 2000). Halamová and colleagues (2018) asked psychology students to supply associations related to 'compassion' and 'self-compassion'. Lukšík and Guillaume (2018) used free associations to obtain descriptions of social representations of 'love' from education and psychology students. Urban (2017) used art-related terms to elicit representations from art students. Dany et al. (2014) asked secondary school students about academic success. In these studies, it was important to examine the representations of particular concepts from the unique perspective of the homogenous social group. As Halamová and colleagues (2018) argue, it is important for psychologists to understand compassion so they can express it to their clients. Urban (2017) revealed how different art-related concepts became part of the identity of the art students in later years of study.

Free associations tend to differ among sociocultural groups and researchers are interested in the differences in the associations produced by different groups. Marková et al. (1998) investigated political, ideological and economic terms in six Central and Western European countries. Urban (2014) asked groups of Slovak and Czech secondary school students to provide associations for Slovak and Czech film to examine adolescent perceptions of national cinematography. In their first study, Rozin and colleagues (2002) described cross-cultural differences in associations to the word 'food' produced by American, French and Indian adults. In their second study, they examined differences between groups of psychology students, their parents and their grandparents in an American population.

Free associations are also often employed in applied marketing research. It is used to investigate associations related to particular brands (such as 'Coca-Cola') and these can be treated as associations relating to a product or a company (Chen, 2001; Koll, von Wallpach, $\&$ Kreuzer, 2010). The emotional valence of the associations (whether they are mostly positive or negative) is often used as a diagnostic tool for identifying brand perception in different groups of consumers (McDowell, 2004). For our purposes it is important to note that free associations are often elicited in marketing research in response to different kinds of image (such as logos or photographs) stimuli (Koll et al., 2010).

\section{Research goals}

In the present study, we examine free associations produced by two different social groups of art students - international and domestic — in response to photographs of outdoor billboards in two distant parts of the city. 
The first aim is to describe the differences and commonalities between local students and students who are not familiar to the local culture. As we argued above, outdoor advertising often conflicts with the local culture (Hartono et al., 2017; Lloren, 2017; Pacoma, 2017).

The second aim is to describe the commonalities and differences between the associations elicited by the billboards in the city centre and the locality on the outskirts. Koleček (2018) and Pavlíček (2015) show that a city's cultural development is irregular and dependent on the location. Therefore we aim to explore how this urban development is reflected by the free associations.

\section{Methods}

\section{Sample}

The participants were postgraduate art students at Jan Evangelista Purkyně University in Ústí nad Labem. We assumed that art students have more experience of different kinds of visual stimuli and are therefore better able to produce more nuanced associations. The group of international students consisted of four students of mean age 30.5 years $(S D=1.5)$. The group of domestic students consisted of four students of mean age $25.75(S D=0.83)$.

\section{Testing materials}

All the outdoor billboards in the two selected areas of Ústí nad Labem were photographed by the second and third authors. Appendix A shows the a) central and b) non-central locations where the photos were taken. The central area of the city contained 36 billboards. The noncentral area contained 49 billboards. Appendix B shows examples of billboards in the central and non-central locations. All the photographs of the billboards were used as stimuli for production of associations.

\section{Procedure}

Photographs of the billboards were projected onto a projector screen with the instructions "... please write down all the associations that come into your mind when you see the picture on the screen”. In line with previous social psychology research (Rozin et al., 2002), there was a time limit of one minute for each picture. This time restriction is used to prevent associations that are too personal (Rosen \& Russell, 1957).

\section{Data analysis}

In order to understand the structure of and the relationships between the free associations, we decided to involve the students in the analysis (similarly to Plichtová, 1991). After the data collection, each group of students was given two electronic documents (one for the central location and one for the non-central location) containing their free associations. For the data analysis of each set of associations, separate analytical sessions were held with the group of international students and the group of domestic students under the supervision of a trained 
researcher (the first author). During these sessions, the students had two objectives: they had to a) categorize their free associations and then b) organize the categories using a conceptual map. The analysis was conducted as a consensus-seeking facilitated discussion. At the end of the sessions, another trained researcher (the fourth author) acted as auditor and checked the categories and map of the relationships between them and provided feedback on the analysis (similarly to Halamová et al., 2018; Hill, 2012).

\section{Results}

\section{Associations for the city centre billboards}

The domestic students produced $N=223$ associations and the international students produced $N=136$ associations in response to the city centre billboards. As reported in Table 1, they placed the associations into 15 different categories. Eight of the categories were the same for both student groups. These contained $77 \%$ of all the associations produced by the

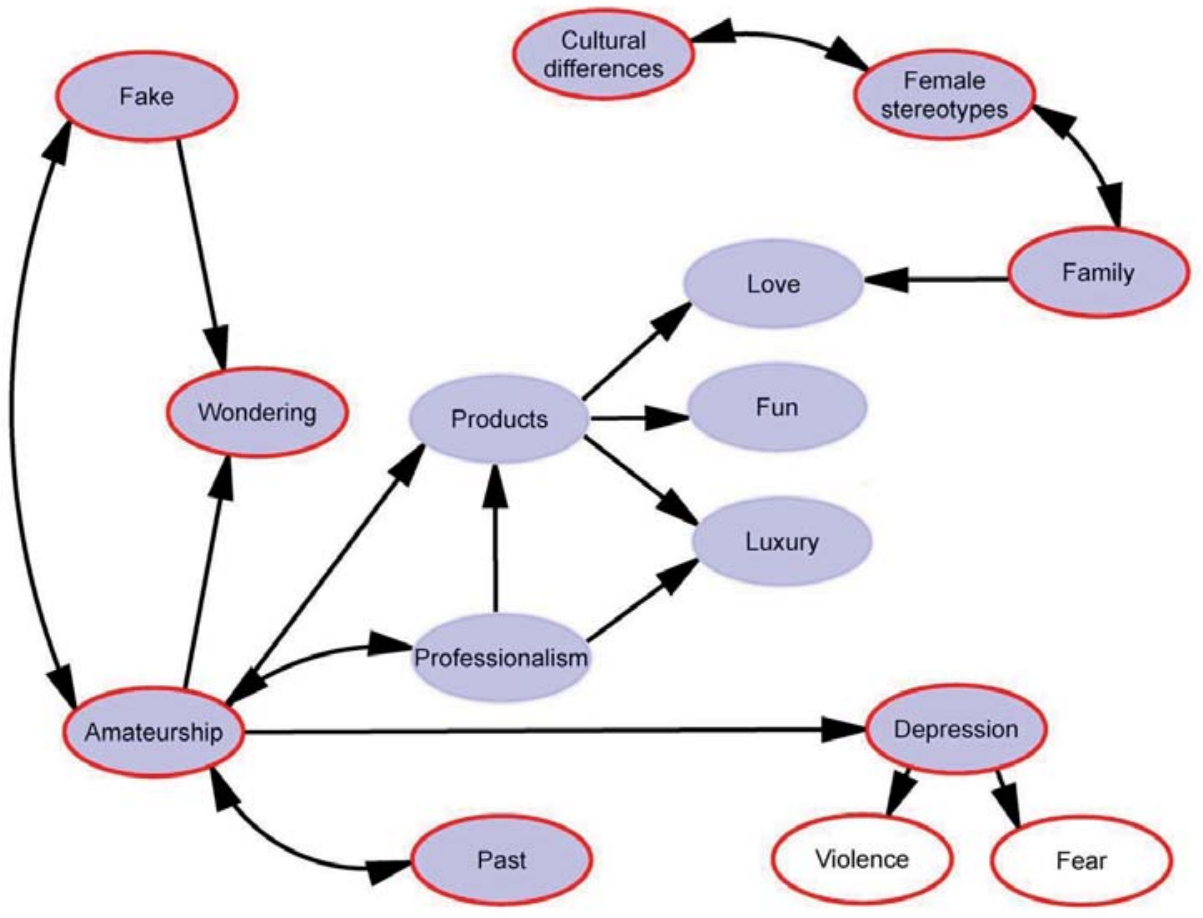

Figure 1. The conceptual map for the categories of associations in the city centre. Note: blue fill and red frame are shared categories; blue fill are categories produced by domestic students; red frame are categories produced by international students. Arrows indicate relationship between categories. 
Table 1. Categories, definitions of categories, three most frequent associations and number of associations (percentage of the sample) produced for city centre billboards by domestic and international students.

\begin{tabular}{|c|c|c|c|c|}
\hline Category & Definition & Examples & $\begin{array}{c}\mathrm{N} \text { of } \\
\text { associations } \\
\text { by domestic }\end{array}$ & $\begin{array}{c}\mathbf{N} \text { of asso- } \\
\text { ciations by } \\
\text { international }\end{array}$ \\
\hline $\begin{array}{l}\text { Female } \\
\text { stereotypes }\end{array}$ & $\begin{array}{l}\text { refers to female roles in } \\
\text { family and society, body } \\
\text { care, sex and age }\end{array}$ & $\begin{array}{l}\text { sexist, forced to smile, } \\
\text { pink }\end{array}$ & $65(28.7 \%)$ & $19(14 \%)$ \\
\hline Fake & $\begin{array}{l}\text { refers to inauthenticity of } \\
\text { advertisements }\end{array}$ & $\begin{array}{l}\text { fake, manipulation, } \\
\text { artificial }\end{array}$ & $32(14.3 \%)$ & $38(27.9 \%)$ \\
\hline Amateurish & $\begin{array}{l}\text { refers to amateur design } \\
\text { of the billboards }\end{array}$ & $\begin{array}{l}\text { graphical waste, } \\
\text { pathetic, disgusting }\end{array}$ & $25(11.2 \%)$ & $24(17.6 \%)$ \\
\hline Wondering & $\begin{array}{l}\text { refers to consternation of } \\
\text { participants }\end{array}$ & $\begin{array}{l}\text { what the hell?, absurd, } \\
\text { what? }\end{array}$ & $21(9.4 \%)$ & $9(6.6 \%)$ \\
\hline Family & refers to family members & $\begin{array}{l}\text { children, happy family, } \\
\text { girl }\end{array}$ & $8(3.6 \%)$ & $8(5.9 \%)$ \\
\hline Past & $\begin{array}{l}\text { refers to vintage style of } \\
\text { billboards }\end{array}$ & $\begin{array}{l}\text { old-school, retro, } \\
\text { vintage }\end{array}$ & $8(3.6 \%)$ & $5(3.7 \%)$ \\
\hline Depression & $\begin{array}{l}\text { refers to symptoms of } \\
\text { depression }\end{array}$ & $\begin{array}{l}\text { melancholy, illness, } \\
\text { emptiness }\end{array}$ & $7(3.1 \%)$ & $19(14.0 \%)$ \\
\hline $\begin{array}{l}\text { Cultural } \\
\text { differences }\end{array}$ & $\begin{array}{l}\text { refers to cultural imports } \\
\text { that don't fit the culture }\end{array}$ & $\begin{array}{l}\text { contrast, blacks for } \\
\text { whites, difference }\end{array}$ & $7(3.1 \%)$ & $2(1.5 \%)$ \\
\hline Luxury & refers to luxury products & luxury, elegance, pure & $15(6.7 \%)$ & - \\
\hline Fun & $\begin{array}{l}\text { refers to humorous } \\
\text { associations }\end{array}$ & fun, comedy, humour & $14(6.3 \%)$ & 一 \\
\hline Products & $\begin{array}{l}\text { refers to content of } \\
\text { advertisements }\end{array}$ & sweets, tea, meat & $10(4.5 \%)$ & - \\
\hline Professionalism & refers to billboard quality & $\begin{array}{l}\text { effective, nice photo, } \\
\text { campaign }\end{array}$ & $7(3.1 \%)$ & - \\
\hline Love & $\begin{array}{l}\text { refers to romantic } \\
\text { associations }\end{array}$ & $\begin{array}{l}\text { romantic, fall in love, } \\
\text { honesty }\end{array}$ & $4(1.8 \%)$ & - \\
\hline Fear & refers to sources of fear & threat, horror, scared & - & $8(5.9 \%)$ \\
\hline Violence & $\begin{array}{l}\text { refers to crimes and } \\
\text { brutality }\end{array}$ & $\begin{array}{l}\text { torture, murderer, child } \\
\text { abuse }\end{array}$ & - & $4(2.9 \%)$ \\
\hline Total $N$ & & & 223 & 136 \\
\hline
\end{tabular}

domestic students and $91.2 \%$ of all the associations produced by the international students. The domestic students placed the remaining associations in the most positive categories (e.g. professionalism, fun, luxury, love). The international students produced associations coming under the negative categories of fear and violence. In Figure 1 we can see the relationships among the categories.

On closer examination of the conceptual map in Figure 1, we can see that there are two sets of associations that are common to both student groups and two sets that are 
unique (one to the domestic students and one to the international students). The first common set is related to the amateur design of the billboards (categories of amateurish, fake and wondering). The students thought the outdoor advertising in the city centre was inauthentic, and they were concerned by the poor quality. The students thought the city centre advertisements would not attract customers. This set was more frequent in the group of international (52.1\% of all associations) than in the group of domestic students $(34.9 \%)$.

The second common set relates to stereotypes (with the categories of female stereotypes, cultural differences and family). Unlike the previous set, the stereotype associations were more frequent among the domestic students (35.4\% of all associations) than among the international students $(21.4 \%)$.

Interestingly the international students created a specific set of depression-related categories (depression, crime and fear), accounting for $22.8 \%$ of all their associations, while the domestic students mentioned only depression (in $3.1 \%$ of cases).

By contrast the domestic students created the specific set of product-related categories (featuring professionalism in contrast to amateurish, and luxury, fun and love as the outcomes of products). This set contained mainly positive associations and accounted for $22.4 \%$ of all the associations.

\section{Associations for billboards on the city outskirts}

Table 2 shows categories of associations for the billboards in the non-central part of the city. In total 20 categories were created, and 9 were common to both student groups. The common categories contained $69.2 \%$ of all the associations produced by the domestic students and $75.9 \%$ of all the associations produced by the international students. The remaining associations produced by the domestic students were put into six categories referring mostly to unpleasant feelings connected to products and materialism. By contrast, the international students produced associations that fit into five negative categories such as crime, fear and prison. As can be seen in Figure 2, the unique categories enrich the sets of shared categories.

The conceptual map of associations produced in response to the peripheral billboards contained four of the same sets as the conceptual map of the city centre associations, but with a slight change in meaning and emotional valence. The amateurish design of the billboards remained the same; the set of stereotypes was enriched by male stereotypes (in the city centre there were only female stereotypes); the set of products shifted towards materialism and became more negatively connoted as unpleasant and ordinary; and depression shifted towards city decay and danger.

In the set relating to the amateur design of the billboards (the categories of amateurish, fake and wondering) the domestic students produced $37.5 \%$ of all the associations, and the international students $46.7 \%$. However, the domestic students' emphasized associations with amateurish (28\%), while the international students emphasized associations with fake (27.7\%).

The set relating to stereotypes consisted of the categories of gender stereotypes and cultural differences. However, the number of associations was small in both groups of students (5.8\% for the domestic group and 6.6\% for the international group).

The set relating to products consisted of one shared and positively connotated category, playfulness, and four negatively connotated categories specific to the domestic students 


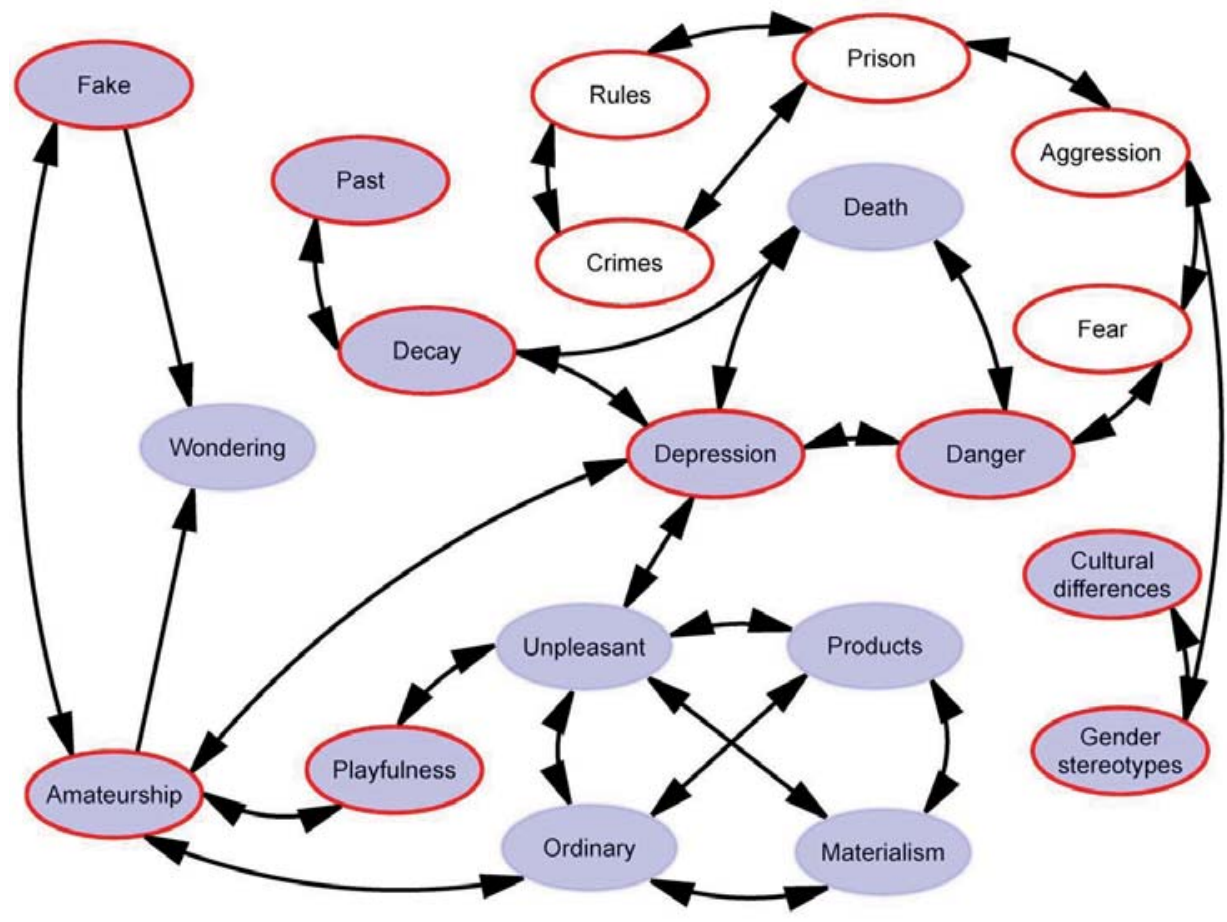

Figure 2. The conceptual map for the categories of associations in the non-central area. Note: blue fill and red frame are shared categories; blue fill are categories produced by domestic students; red frame are categories produced by international students. Arrows indicate relationship between categories.

(products, materialism, unpleasant and ordinary). The domestic students produced $21.1 \%$ of the associations in this set and the international ones 3.6\%.

The last set related to depression, but in the context of the shared categories of past, decay and danger. There was one unique category produced by the domestic group (death) and five unique categories produced by the international group (fear, aggression, crime, rules and prison). The domestic group produced $35.4 \%$ of the associations in this set and the international group $45.2 \%$. As we can see, the students thought the billboards on the outskirts of the city were in poor condition and elicited extremely negative responses. 
Table 2. Categories, definitions of categories, three most frequent examples of associations and number of associations (percent of sample) produced for billboards in the peripheral location by domestic and international students.

\begin{tabular}{|c|c|c|c|c|}
\hline Category & Definition & Examples & $\begin{array}{c}\text { Nof } \\
\text { associations } \\
\text { by domestic }\end{array}$ & $\begin{array}{c}\text { Nof asso- } \\
\text { ciations by } \\
\text { international }\end{array}$ \\
\hline Amateurish & refers to billboard design & $\begin{array}{l}\text { lacking an idea, ugly, } \\
\text { clichéd }\end{array}$ & $53(28.0 \%)$ & $26(19.0 \%)$ \\
\hline Decay & $\begin{array}{l}\text { refers to dilapidated } \\
\text { billboards }\end{array}$ & closed, dirt, degradation & $19(10.1 \%)$ & $8(5.8 \%)$ \\
\hline Depression & $\begin{array}{l}\text { refers to symptoms of } \\
\text { depression }\end{array}$ & sad, emptiness, depression & $17(9.0 \%)$ & $9(6.6 \%)$ \\
\hline Past & $\begin{array}{l}\text { refers to vintage style } \\
\text { billboards }\end{array}$ & old-school, retro, old & $14(7.4 \%)$ & $3(2.2 \%)$ \\
\hline Playfulness & refers to relaxed feelings & $\begin{array}{l}\text { funny, good feeling, } \\
\text { comfort of home }\end{array}$ & $8(4.2 \%)$ & $5(3.6 \%)$ \\
\hline $\begin{array}{l}\text { Gender } \\
\text { stereotypes }\end{array}$ & $\begin{array}{l}\text { refers to male and female } \\
\text { stereotyped perception }\end{array}$ & $\begin{array}{l}\text { pink and women, angelic } \\
\text { hair, alpha male }\end{array}$ & $7(3.7 \%)$ & $3(2.2 \%)$ \\
\hline Danger & refers to dangerous places & $\begin{array}{l}\text { I hate the military, army, } \\
\text { danger }\end{array}$ & $5(2.6 \%)$ & $6(4.4 \%)$ \\
\hline Fake & $\begin{array}{l}\text { refers to unauthenticity of } \\
\text { advertisements }\end{array}$ & $\begin{array}{l}\text { fake ad, artificial, luxury } \\
\text { - no way }\end{array}$ & $4(2.1 \%)$ & $38(27.7 \%)$ \\
\hline $\begin{array}{l}\text { Cultural } \\
\text { differences }\end{array}$ & $\begin{array}{l}\text { refers to cultural imports } \\
\text { that do not fit the culture }\end{array}$ & $\begin{array}{l}\text { import, against nature, } \\
\text { foreign }\end{array}$ & $4(2.1 \%)$ & $6(4.4 \%)$ \\
\hline Wondering & $\begin{array}{l}\text { refers to consternation of } \\
\text { participants }\end{array}$ & $\begin{array}{l}\text { what the hell?, strange, } \\
\text { bizarre }\end{array}$ & $14(7.4 \%)$ & - \\
\hline Unpleasant & $\begin{array}{l}\text { refers to uncomfortable } \\
\text { feelings }\end{array}$ & $\begin{array}{l}\text { boredom, annoying, } \\
\text { distrust }\end{array}$ & $12(6.3 \%)$ & - \\
\hline Death & $\begin{array}{l}\text { refers to places, styles and } \\
\text { products related to death }\end{array}$ & $\begin{array}{l}\text { like an obituary, dead fish, } \\
\text { funeral service }\end{array}$ & $12(6.3 \%)$ & - \\
\hline Materialism & refers to consumerism & $\begin{array}{l}\text { shopping, store, fashion } \\
\text { ad }\end{array}$ & $7(3.7 \%)$ & - \\
\hline Ordinary & refers to mediocrity & $\begin{array}{l}\text { moderate, every day, } \\
\text { minimalism }\end{array}$ & $7(3.7 \%)$ & - \\
\hline Products & $\begin{array}{l}\text { refers to content of } \\
\text { advertisements }\end{array}$ & $\begin{array}{l}\text { chicken everywhere, } \\
\text { pharmacy, farm }\end{array}$ & $6(3.2 \%)$ & - \\
\hline Crime & refers to different crimes & $\begin{array}{l}\text { gangster, drugs, money } \\
\text { laundering }\end{array}$ & - & $8(5.8 \%)$ \\
\hline Fear & $\begin{array}{l}\text { refers to the emotion of } \\
\text { fear }\end{array}$ & fear, scary, dark window & - & $8(5.8 \%)$ \\
\hline Aggression & refers to acts of brutality & $\begin{array}{l}\text { violence, forced, } \\
\text { aggressive }\end{array}$ & - & $7(5.1 \%)$ \\
\hline Prison & refers to captivity & $\begin{array}{l}\text { prison, cage, divide } \\
\text { people }\end{array}$ & - & $7(5.1 \%)$ \\
\hline Rules & refers to norms & official, strict, serious & - & $3(2.2 \%)$ \\
\hline Total $N$ & & & 189 & 137 \\
\hline
\end{tabular}




\section{Discussion}

\section{Outdoor advertisement considered amateurish by art students}

The research participants belonged to a specific group: they were postgraduate art students. Art students may well produce billboard images in the future, so we were interested in their views of the outdoor advertising. Miyai and colleagues (2019) found that art students differed in their views of abstract impressions based on their knowledge and experience. It is for this reason that our sample consisted of a group of domestic and international art students. In our research all the students thought the billboards were amateurish. They described the billboards as lacking an idea, graphic waste, and thought the images were clichéd, ugly or obviously photoshopped, while the fonts were poorly chosen. Moreover, they thought the advertisements were inauthentic, artificial, insincere, fake or mock. These results raise important questions about perceptions of the products advertised and whether these billboards fulfil their basic function of improving product sales.

Peng (2017) found that the more students considered the advertisement to be art, the more they liked it, and thought the product luxurious. In our research, the group of domestic students generated the categories of professionalism (with associations like nice photos) and products connected to luxury, love and fun. Phillips and McQuarrie (2010) show that advertising achieves these idealized beauty aesthetics by using photographs of beautiful girls, luxury products and appropriate backgrounds (see also Zarzosa \& Huhmann, 2019).

\section{Female stereotypes in the city centre}

In 2003 an analysis of a selection of newspapers, magazines, television programmes and television news broadcasts was conducted in the Czech Republic (TNS Factum, 2003). Researchers found that the 'traditional roles and activities' of women were mainly related to sex, birth and raising children, and looking after the family and home. They concluded that advertisements portray women simply to elicit interest. The results supported the findings of the Council of Europe, which examined the relationship between the media and representations of women. It concluded that the media reproduce stereotypes and objectified representations of women (Sarikakis, 2013).

In the present study, we found a large number of the free associations elicited by the city centre advertisements related to female stereotypes. Women were portrayed as naked or halfnaked sexual objects (associations like targeted at men and sexist) with perfect bodies and a forced smile. We also found that the billboards reproduced stereotypical views that women are kind and belong in the household (Výrost, 2011). Associations like pink are linked to the beauty myth (Cviková \& Juráňová, 2006) disseminated by the media and in fairy tales to children from an early age (Urban \& Urban, 2017). Surprisingly, the female stereotypes that were commonly found on the city centre billboards were almost absent from the peripheral billboards. Yet the billboards in the outskirts copied the beauty myth for women and in addition represented strong and aggressive men (Lenton, Bruder, \& Sedikides, 2009; Urban \& Urban, 2017).

The presence and absence of female stereotypes in the central and non-central locations can be explained by the category of products. While the products advertised in the city centre were associated with luxury, fun or love with women being used to attract customer 
interest (TNS Factum, 2003), in the outskirts the products were mainly described negatively as ordinary and unpleasant. This emphasis is transferred from the stereotypes to the poor physical state of the billboards, reffering to their actual decay.

\section{Decay in the city outskirts}

One of the four main reasons marketeers use billboards is the potential tangible response from customers seeing the advertised products (Taylor et al., 2006). Our research of the free associations elicited by the billboards in the city outskirts showed that these advertisements did not attract customers, but more likely deterred them. Besides noting the amateurish nature of the advertisements, the students mentioned decay, past, depression and danger. The domestic students included death in this list, and the international students included fear, aggression, prison and crime.

Koleček (2018) explains that the urban identity of Ústí nad Labem is influenced specifically by its location and totalitarian history (the city is close to the Czech-German border and its inhabitations were forcibly expelled after World War II based on the principle of collective guilt). Pavliček (2015) states that cultural memory determines the shape of the city, its urbanism, aesthetics and demography. It is therefore plausible that the free associations relating to decay, past, depression, danger and fear refer not only to the condition of the billboards but also the state of the city. While the city centre is mainly defined by female stereotypes, the city outskirts is portrayed as in a state of decay. Both of these findings are alarming.

\section{Future perspectives}

The billboards are highly visible. Viewers cannot choose whether to look at them or not; instead the billboards force their content upon the public. This phenomenon is usually understood as highly negative, especially where stereotypes are concerned (Pacoma, 2017). Different kinds of interventions, regulations and strategies have been discussed in relation to tackling these potentially harmful effects of outdoor advertisements (Baker, 2007). Most visibly, São Paulo the largest city in Brazil, banned outdoor advertisements in 2007 (Koeck $\&$ Warnaby, 2014). However, Elrod and Fortenberry (2017) argue that while we cannot avoid seeing billboards, we can exploit their visibility and advertise socially beneficial issues. They propose creating billboard content to help socially disadvantaged individuals, using prejudice reduction strategies (e.g. displaying desirable behaviour).

Nevertheless, the free associations in our research depicted characteristics of outdoor billboards like low quality (amateurish, fake), problematic content (stereotypes, cultural differences), and more importantly, captured the general atmosphere of the particular neighbourhood (decay, depression, fear). Our participants were postgraduate art students, but it would be beneficial to continue the research with the general public, as the public (at least in the United States) is keen on outdoor advertising despite its negative effects (Franke \& Taylor, 2017). Free associations are often used in marketing research (Koll et al., 2010; McDowell, 2004), and our research has shown they are also useful in understanding billboard advertising and can provide valuable insights into the topic of visual pollution. 


\section{References}

Baker, L. E. (2007). Public sites versus public sights: the progressive response to outdoor advertising and the commercialization of public space. American Quarterly, 59(4), 1187-1213.

Bollas, Ch. (2008). The evocative object world. New York, NY: Routledge.

Chen, A. C.-H. (2001). Using free association to examine the relationship between the characteristics of brand associations and brand equity. Journal of Product \& Brand Management, 10(7), 439-451.

Chmielewski, S., Lee, D. J., Tompalski, P., Chmielewski T. J., \& Wężyk, P. (2016): Measuring visual pollution by outdoor advertisements in an urban street using intervisibilty analysis and public surveys. International Journal of Geographical Information Science, 30(4), 801-818.

Correa, V. F., \& Mejía, A. A. (2015). Indicadores de contaminación visual y sus efectos en la población. Enfoque UTE, 6(3), 115-132.

Cviková, J., \& Juráňová, J. (2006). Ružový a modrý svet: Rodové stereotypy a ich dôsledky [Pink and blue world: Gender stereotypes and their consequences] [online]. Bratislava: Aspekt, 2006. Available at: http://www.ruzovyamodrysvet.sk/sk/hlavne-menu/citaren/ruzovy-a-modry-svet-(cdrom)

Dany, L., Urdapilleta, I., \& Lo Monaco, G. (2015). Free associations and social representations: Some reflections on rank-frequency and importance-frequency methods. Quality \& Quantity, 49(2), 489507.

Elrod, J. K. \& Fortenberry, J. L. (2017). Billboard advertising: an avenue for communicating healthcare information and opportunities to disadvantaged populations. BMC Health Services Research, 17(Suppl 4), 787.

Franke, G. R., \& Taylor, C. R. (2017). Public perceptions of Billboards: A Meta-Analysis. Journal of Advertising, 46(3), 395-410.

Halamová, J., Baránková, M., Strnádelová, B., \& Koróniová, J. (2018). Consensual qualitative research on free associations for compassion and self-compassion. Human Affairs, 28(3), 253-270.

Hartono, H. S., Davies, S. G., \& Macrae, G. (2017). 'You can't avoid sex and cigarettes': How Indonesian Muslim mothers teach their children to read billboards. Pacific journalism review, 23(2), 179-196.

Hill, C. E. (2012). Consensual qualitative research: A practical resource for investigating social science phenomena. Washington, DC: American Psychological Association.

Koeck, R. \& Warnaby, G. (2014). Outdoor advertising in urban context: spatiality, temporality and individuality. Journal of Marketing Management, 30(13-14), 1402-1422.

Koleček, M. (2018). A Work of Art at the Centre of Public Interest - Stories, Characters, Forms and Values in the Process of Social Representation. In M. Fleming, \& A. Lukaszewicz Alcaraz (Eds.), Visuality from Intercultural Perspectives. Technology of Images in Communication, Art and Social Sciences. London, Szczecin: PUNO PRESS, 114-139.

Koll, O., von Wallpach, S., \& Kreuzer, M. (2010). Multi-Method research on consumer-brand associations: Comparing free associations, storytelling, and collages. Psychology \& Marketing, 27(6), 584-602.

Kris, A. O. (2018). Free Association: Method and Process. London: Routledge.

Lenton, Alison P., Bruder, M., \& Sedikides, C. (2009). A Meta-Analysis on the malleability of automatic gender stereotypes. Psychology of Women Quarterly, 33(2), 183-196.

Lloren, G. S. (2017). Socio-Cultural Appropriation of Sex-Sell Billboard Ads: A Multimodal Study on the Grammar of Sexually Implicit Advertising Text and Images. Plaridel, 14(2), 1-24.

Lukšík, I., \& Guillaume, M. (2018). Representations of love in the early stages of love. Human Affairs, 28(3), 271-284.

Marková, I., Moodie, E., Farr, R. M., Drozda-Senkowska, E., Erös, F, ... , Mullerová, O. (1998). Social representations of the individual: A post-Communist perspective. European Journal of Social Psychology, 28, 797-829. 
McDowell, W. S. (2004). Exploring a free association methodology to capture and differentiate abstract media brand associations: A study of three cable news networks. Journal of Media Economics, 17(4), 309-320.

Miyai S., Katahira K., Sugimoto M., Nagata N., Nikata K., Kawasaki K. (2019) Hierarchical Structuring of the Impressions of 3D Shapes Targeting for Art and Non-art University Students. In Stephanidis C. (Ed.) HCI International 2019 - Posters. HCII 2019. Communications in Computer and Information Science, vol 1032 (pp. 385-393). Cham: Springer.

Nelson, D. L., McEvoy, C. L., \& Dennis, S. (2000). What is free association and what does it measure? Memory \& Cognition, 28, 887-899.

Nowghabi, A. S., \& Talebzadeh, A. (2019). Psychological Influence of Advertising Billboards on City Sight. Civil Engineering Journal, 5(2), 390-397.

Out of Home Advertising Association of America. (2019). OOH Glossary of Terms. Washington: OAAA.

Pacoma, M. A. (2017). Sexual Objectification of Pinoy Males in Billboard Advertisements, presented at i-COME'16, Kuala Lumpur, Malaysia, 2016. London: EDP Sciences.

Pavlíček, T. (2015). The City as a Social Space for the Creation of Cultural Values: Between the Intimate and Institutional Traditions. In The limits of Heritage. Kraków: International Cultural centre, 469-490.

Peng, H. (2017). Young peoples' attitudes on art infusion advertising on social media: Focus groups with Chinese students (Master's thesis). Retrieved from ETDs: Virginia Tech Electronic Theses and Dissertations. http://hdl.handle.net/10919/78373

Phillips, B. J., \& McQuarrie, E. F. (2010). Narrative and Persuasion in Fashion Advertising. Journal of Consumer Research, 37(3), 368-392.

Plichtová, J. (1991). Medzinárodný seminár o nacionalizme [International seminar about nationalism]. Bratislava: Academia Istropolitana.

Plichtová, J. (2002). Metódy sociálnej psychológie zblízka: Kvalitatívne a kvantitatívne skúmanie sociálnych reprezentácii. [Social psychology methods up close. Qualitative and quantitative studies of social representations]. Bratislava: Médiá.

Portella, A. (2014). Visual pollution: advertising, signage and environmental quality. Farnharm: Ashgate Publishing.

Rosen, E., \& Russell, W. A. (1957). Frequency characteristics of successive word associations. American Journal of Psychology, 70, 120-122.

Rozin P., Kurzer, N., \& Cohen, A. B. (2002). Free associations to "food:" the effects of gender, generation, and culture. Journal of Research in Personality, 36(5), 419-441.

Sarikakis, K. (2013). Media and the image of women: Report of the 1st Conference of the Council of Europe Network of National Focal Points on Gender Equality. Amsterdam: Council of Europe.

Stocchetti, M. (2014). Images and Power in the Digital Age: The political role of digital visuality. KOME - An International Journal of Pure Communication Inquiry, 2(2), 1-16.

Stocchetti, M. (2017). Digital Visuality and Social Representation. Research Notes on the Visual Construction of meaning. KOME - An International Journal of Pure Communication Inquiry, 5(2), 38-56.

Taylor, R., Franke, C. R., \& Bang, H.-K. (2006). Use and Effectiveness of Billboards: Perspectives from Selective-Perception Theory and Retail-Gravity Models. Journal of Advertising, 35(4), 21-34.

TNS Factum (2003). Obraz ženy v médiích a reklamě a jeho vliv na veřejné mínění o rovnosti mužu $a \check{z}$ en [The image of women in the media and advertising and its influence on public opinion on gender equality]. Praha: TNS Factum.

Urban, M. (2014). Existuje slovenský film? Výskum sociálnych reprezentácií "slovenského" a "českého filmu" u študentov stredných škôl [Does Slovak Film Exist? Social representations of "Slovak“ and „Czech“ film in high school students]. Kino-Ikon: časopis pre vedu o filme a "pohyblivom obraze», 18(2) 138-154. 
Urban, M. (2017). Identita autora: Príbehy, sociálne reprezentácie a naratívne Self v slovenskej kinematografii v rokoch 2012 - 2017 [Identity of the Auteur: Narratives, Social Representations and Narrative Self in Slovak Cinematography in 2012-2017]. Bratislava: Veda.

Urban, M., \& Urban, K. (2017). The representation of men and women in contemporary Slovak films aimed at children. Slovenské divadlo, 65(1), 63-81.

Vardavas, C. I., Connolly, G. N., \& Kafatos, A. G. (2009). Geographical information systems as a tool for monitoring tobacco industry advertising. Tobacco Control, 18(3), 190-196.

Výrost, J. (2011). Rodina a zmena rodových rolí v optike údajov medzinárodného projektu ISSP [Family and changes in gender roles as viewed through ISSP (International Social Survey Programme) data]. Košice: Spoločenskovedný ústav SAV.

Zarzosa, J., \& Huhmann, B. A. (2019). Measures of aesthetic dimensions and reactions in advertising. International Journal of Advertising, 38(2), 258-275.

${ }^{1}$ Department of History and Theory of Art,

Faculty of Art and Design,

Jan Evangelista Purkyně University

Pasteurova 9

40096 Ústí nad Labem

Czech Republic

Email: marek.m.urban@gmail.com

${ }^{2}$ Department of Photography,

Faculty of Art and Design,

Jan Evangelista Purkyně University

Pasteurova 9

40096 Ústí nad Labem

Czech Republic

Email: danyvigil@gmail.com

Email: milosbjvc@gmail.com

${ }^{3}$ Institute for Research in Social Communication,

Slovak Academy of Sciences

Dúbravská cesta 9

84511 Bratislava

Slovakia

Email: kamila.urban@savba.sk

${ }^{4}$ Institute of Education and Communication,

Czech University of Life Sciences

V Lázních 3

15900 Prague

Czech Republic 


\section{APPENDIX A}

City map of Ústí nad Labem with selected a) central and b) non-central areas where the outdoor billboards were photographed. Note: Copyright (CC-BY-SA) of the map belongs to OpenStreetMap Contributors.

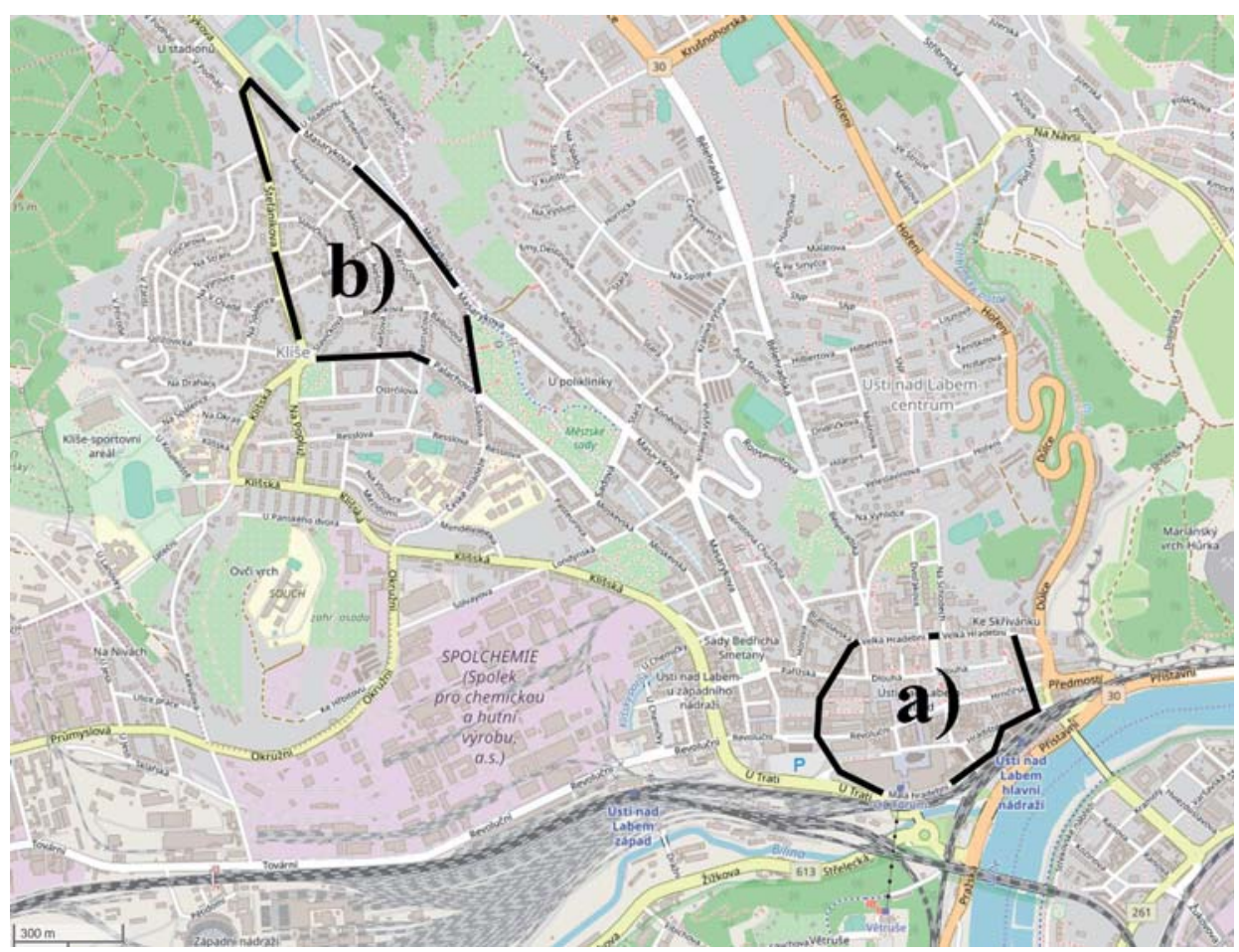




\section{APPENDIX B}

a) An example of a billboard in the city centre.

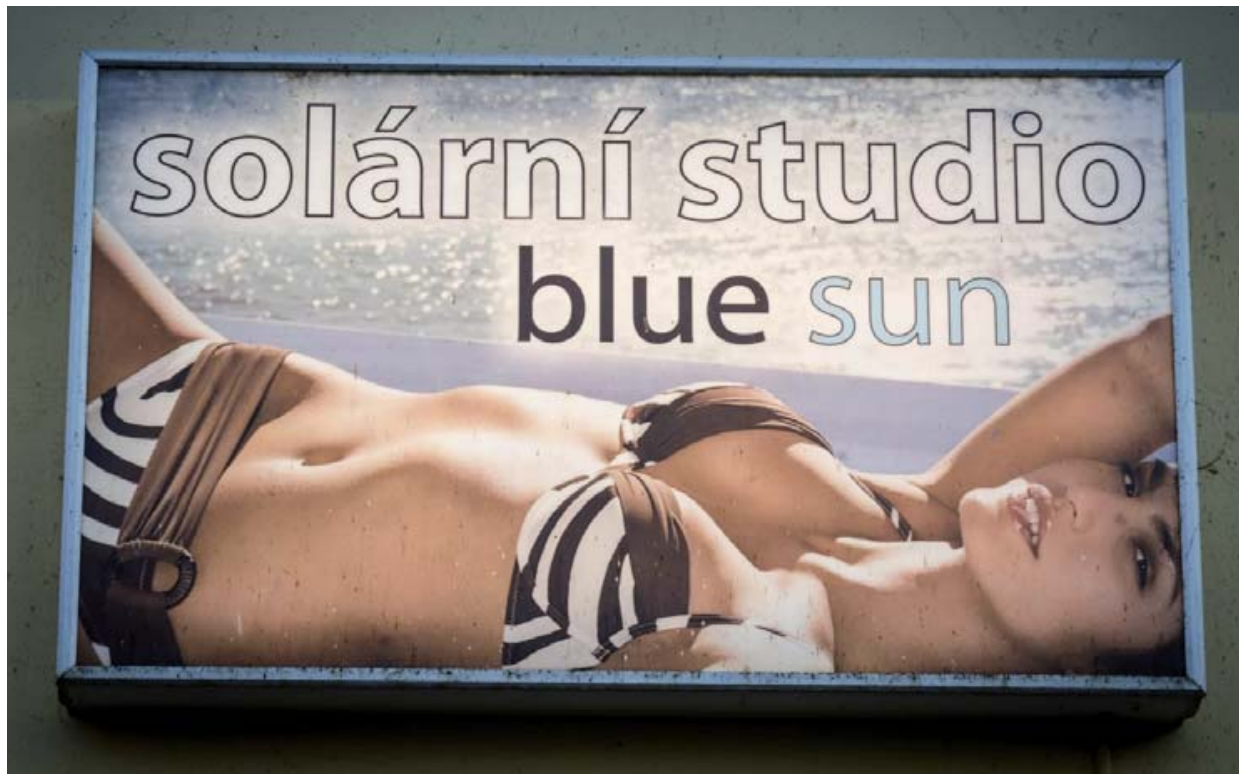

b) An example of a billboard in the outskirts of the city.

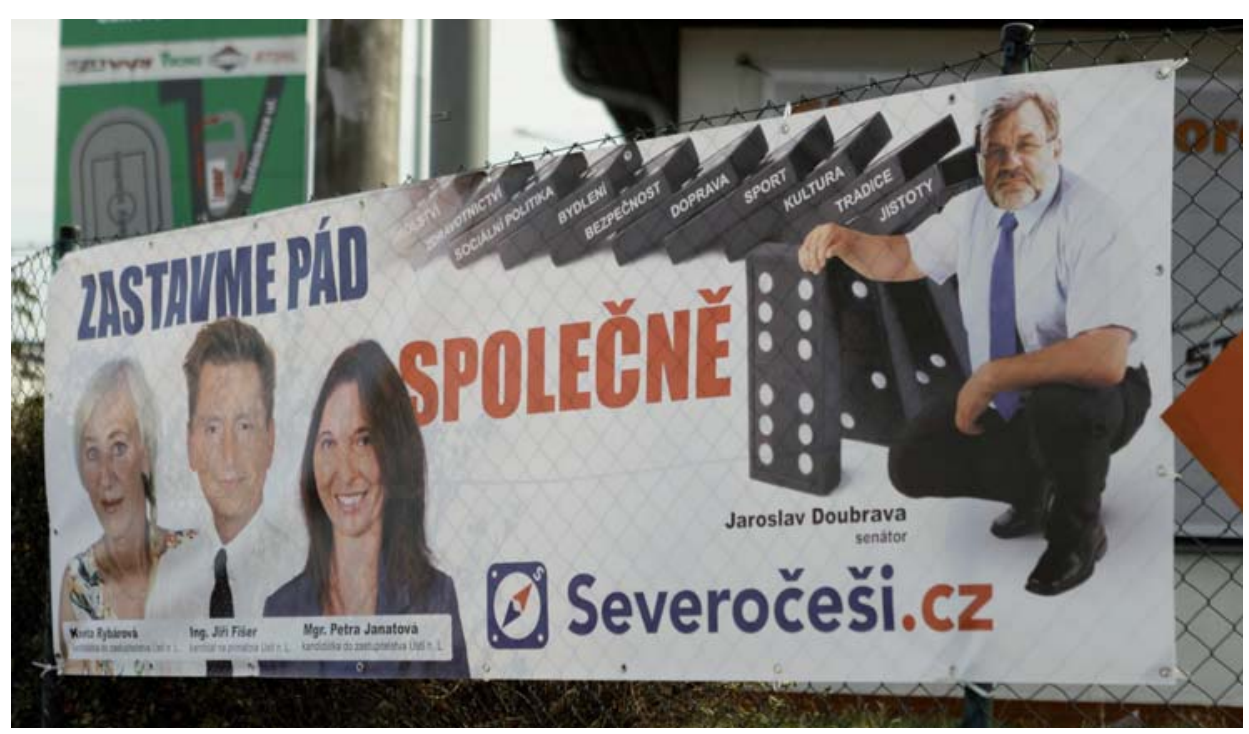

